\title{
Between Rootedness and Rootlessness: How Sedentarist and Nomadic Metaphysics Simultaneously Challenge and Reinforce (Dual) Citizenship Claims for Liberia
}

\author{
Robtel Neajai Pailey \\ Department of International Development, University of Oxford
}

\begin{abstract}
Within the last decade alone, large-scale emigration has emboldened approximately half of all African states to adopt constitutional reforms granting dual citizenship, with some provisions more limited than others. Given Liberia's post-war prominence in the African Union (AU), Economic Community of West African States (ECOWAS) and Mano River Union (MRU), it remains an important case study on the challenges of consolidating extraterritorial citizenship because of mounting pressure to harmonize its citizenship laws with regional institutions.

In this article, I argue that historical and contemporary migration to/from Liberia configured and reconfigured the country's citizenship norms, thereby generating roots for some, routes for others, and a transnational impasse on dual citizenship. Further, I demonstrate that Liberians' notions of rootedness and rootlessness have simultaneously facilitated the introduction and postponement in the passage of a contested dual citizenship bill. While the proposed bill is an attempt to reconcile the (forced) migration of hundreds of thousands before, during, and after intermittent armed conflict in Liberia, it has been postponed because, for some, naturalization abroad signifies a rejection of the fundamental tenets of 'Liberian citizenship' as being rooted in a singular national identity. Using empirical evidence based on interviews with over 200 Liberians in urban centres in West Africa, North America and Europe, I discuss how the divergent citizenship status choices of respondents represent a continuum of nomadic and sedentarist metaphysical thinking thereby simultaneously strengthening and challenging claims for dual citizenship.
\end{abstract}

Keywords: citizenship; dual citizenship; Liberia; migration; nomadic metaphysics; sedentarist metaphysics 


\section{Introduction}

Within the last decade alone, large-scale emigration has emboldened approximately half of all African states to adopt constitutional reforms granting dual citizenship, with some provisions more limited than others (Manby 2009, 2010). Although, admittedly, this trend appears to be global in scale and scope and does not represent African exceptionalism, Africa is a particularly relevant region of analysis given that most of the continent's post-independence citizenship laws represented colonial artefacts that excluded rather than embraced multiple forms of legal national identity (Mamdani 1996; Manby 2009, 2010). Despite reputed gains, the enactment of dual citizenship across the continent has not happened at lightning speed, primarily because of concerns that increased claims for extraterritorial citizenship may be driven as much by selfish political interests as by concerns about national reconstruction, economic development, or security, especially with the advent of multi-party competition, the involvement of emigrants in homeland politics, and the need for African politicians to establish constituencies abroad for support and funding (Whitaker 2011: 756). For instance, although dual citizenship proponents in Liberia and elsewhere argue for enactment based on assumptions about economic advances, there is no empirical evidence that explicitly recognizes a correlation between increased economic contributions by a country's diasporas and the enactment of dual citizenship (Whitaker 2011; Pailey 2014; Pailey 2016).

Given Liberia's post-war prominence in the African Union (AU), Economic Community of West African States (ECOWAS) and Mano River Union (MRU), it remains an important case study on the challenges of consolidating extraterritorial citizenship because there has been mounting pressure on the country to harmonize its citizenship laws with regional institutions. In ECOWAS alone, fourteen out of fifteen countries have enacted some form of dual citizenship legislation, with Liberia serving as a stark outlier (Pailey 2014; Siaplay 2014; Pailey 2016; Manby 2016).

While citizenship reconfiguration processes across the continent of Africa and elsewhere accelerated the introduction of Liberia's proposed dual citizenship bill in $2008^{1}$, backlash against granting extraterritorial citizenship to diasporas has subsequently decelerated passage (Pailey 2014; Pailey 2016). As a case in point, although the bill was rejected by delegates during an April 2015 Constitutional Review Conference, Liberia's House of Representatives voted in November 2016 to include it in a forthcoming, nationwide referendum thus both foregrounding its prominence in public discourse and necessitating scholarly scrutiny (Liberia News Agency 2015; Daily Observer 2016).

In this article, I argue that historical and contemporary migration to/from Liberia configured and reconfigured the country's citizenship norms, thereby generating roots for some, routes for others, and a transnational impasse on dual citizenship. Further, I move beyond claims for and counterclaims against dual citizenship by Africa's politicians and policy makers to demonstrate that ordinary Liberians' notions of rootedness and rootlessness have simultaneously facilitated the introduction and postponement in the passage of the contested dual citizenship bill. This article examines international migration to and from Liberia rather than internal migration within Liberia, primarily because emigration has influenced more significantly than internal migration the proposed legislation. Empirical evidence presented here is based on fieldwork conducted from June 2012 to July 2013 in which I interviewed 202 Liberians across five urban 
centres in West Africa, Europe and North America—namely Monrovia, Liberia; Freetown, Sierra Leone; Accra, Ghana; London, UK; and Washington, DC. ${ }^{2}$

First, I illustrate how sedentarist and nomadic metaphysical thinking have affected underlying assumptions about dual citizenship for Liberia. Second, I trace Liberia's historical and contemporary migration trends, paying close attention to the migratory patterns of respondents in my study. Third, I present an exploration of the citizenship status of respondents and their motivations for naturalizing or not naturalizing abroad. I discuss how the divergent citizenship status choices of respondents represent a continuum of nomadic and sedentarist metaphysical thinking thereby simultaneously challenging and reinforcing claims for dual citizenship. I use inverted commas to encase the term 'Liberian citizenship' throughout the article because it refers to the constantly shifting conceptualizations and practices of citizenship over space and time (Pailey 2014; Pailey 2016).

\section{Contestations over fixity and flow complicate citizenship claims}

Polarized debates about the bounded or unbounded nature of citizenship are mirrored in debates about globalization, pitting those who advocate for the increased relevance of nation-states and territorially bounded citizenship against those who argue that nationstates are not the basic unit of analysis or the custodians of citizenship, but one of many institutions whose powers extend transnationally, such as multilateral agencies, multinational corporations and international NGOs (Glick Schiller 2009: 6; Isin 2000: 2). Therefore, it is important to explore the nuanced ways in which globalization has simultaneously unsettled and entrenched territorially bounded citizenship, as this will serve as the basis for my analysis later of how migration has configured and reconfigured 'Liberian citizenship' across space and time.

On one hand, Marshall's brand of civil, political and social citizenship is based on 'stasis, of the rights and duties attributed to, and available to, those living and working within a given territory by virtue of long-term membership within a given society' (Urry 2000: 63-4). Nevertheless, citizenship brokered by processes of migration and globalization is based on 'flow, concerned with the causes and consequences of the flows across borders of risks, cultures, migrants and visitors, respectively' (Urry 2000: 63-4). Thus globalization has not undermined the institution of citizenship per se, rather it has reconfigured 'the ways in which people think about their sense of citizenship, their sense of belonging and their sense of responsibility' (Desforges et. al 2005: 442). Although some assert that territorially bounded citizenship is more entrenched than ever before in spite of globalization, others argue it has fundamentally lost its relevance, and debates about fixity and flow in citizenship regimes are as relevant in discourses on globalization as they are in debates about migration. Thus, citizenship is embedded in philosophical debates about movement and stasis, simultaneously.

According to Cresswell (2006: 25), there are two paradigms framing mobility and place. On one hand, contemporary social thought depicts nomadism, mobility and rootlessness as 'progressive, exciting, and contemporary' while sedentarism, stasis and rootedness are seen as 'reactionary, dull or of the past'. Furthermore, movement is entrenched in social and political history, in which 'people have always moved, whether through desire or through violence' (Malkki 1992: 24). This can be attributed to the 
motivations for introducing Liberia's dual citizenship bill in 2008, as it represents simultaneously recognition of Liberia's history of migration and conciliation to its emigrants, articulated more fully in the empirical sections of this article (Pailey 2014). The 'nomadic metaphysic', as it is called, 'links mobility to forms of subaltern power...central to the practices of transgression and resistance' (Creswell 2006: 46), and appears closely aligned with arguments in favour of territorially unbounded citizenship, generally, and dual citizenship in Liberia, specifically.

On the other hand, there is an alternative school of thought referred to as the 'sedentarist metaphysic', in which 'people are often thought of, and think of themselves, as being rooted in place and as deriving identity from that rootedness' (Malkki 1992: 27). Supported by claims for maintaining territorially bounded citizenship, this paradigm influences backlash against dual citizenship and the subsequent postponement of the proposed bill in Liberia, as the empirical evidence presented later in this article will demonstrate. Embedded in nationalist discourse and entangled with arborescent metaphors, the 'roots' paradigm frames mobility as pathological, dysfunctional and threatening (Cresswell 2006: 27, 31; Malkki 1992: 27-8). This conceptualization has fundamentally influenced the securitization of migration, where heightened preoccupations with containment have bolstered modern nation-states to adopt restrictive citizenship and visa regimes as well as border controls (Dannreuther 2007: 101, 105-7, 110-11; Duffield 2008: 146, 152-55). According to this frame 'mobility is often the assumed threat to the rooted, moral and authentic existence of place' and mobility involves 'the absence of commitment and attachment and involvement' (Cresswell 2006: 31). This paradigm colours the thinking of opponents of dual citizenship for Liberia; while they may see some migration as involuntary, they often view naturalization abroad as a voluntary abdication of commitment to Liberia and its citizens (Pailey 2014).

Yet, displacement, particularly of refugees, unsettles sedentarist biases in some ways. Just as mobility is seen as unnatural in the sedentarist metaphysic, displacement caused by violence can also be viewed as rupturing the 'natural order of things', in which case refugees fleeing armed conflict cannot be considered aberrations (Pailey 2014). In her empirical study on Hutu refugees in Tanzania, for instance, Malkki discovered that while refugees settled in urban centres juggled multiple identities through partial assimilation, those inhabiting camps staunchly held onto an essentialist construction of national identity bounded by a single geographic territory (Malkki 1992: 35-6). Camp refugeeism became a symbol of cultural purity and a status signifying 'the ultimate temporariness of exile and of the refusal to become naturalized, to put down roots in a place to which one did not belong' (Malkki 1992: 35). In my study as well as in Malkki's, keeping one's citizenship and refusing to assimilate signifies authenticity and rootedness for some, however imagined.

Following this brief theoretical framing is a detailed description of historical and contemporary migration patterns to and from Liberia, with an exploration of how movement across diverse spatial landscapes has configured and reconfigured 'Liberian citizenship'.

\section{This land of migration, not 'liberty'}


Liberia's history is steeped in processes of migration, mobility and flux (Pailey 2014). Whereas movement in the nineteenth century was directed inwards during processes of state formation, the late twentieth and early twenty-first centuries were characterized by unprecedented out-flows precipitated by intermittent armed conflicts. Long before the arrival of black settlers in the nineteenth century, there was significant migration to the territory that is modern-day Liberia. As a case in point, most of Liberia's sixteen ethnolinguistic groups are not 'indigenous' at all. They migrated in several waves, with the Gbandi, Gio, Kpelle, Lorma, Mandingo, Mano, Mende, and Vai arriving between the twelfth and seventeenth centuries from far-flung West African territories such as contemporary Burkina Faso, Guinea, Côte d'Ivoire, Mali, and Sierra Leone (Guannu 1983: 9-10; Konneh 1996: 7-11). Other early documented waves of migration began at the end of the fifteenth century, when Mande-speaking peoples cascaded up the Niger River, settling in present-day Sierra Leone and Liberia (Gershoni 1985: 2). The Mane warriors, whose descendants are the Gbandi and Lorma, constituted another wave of migration as they settled in what is modern-day northern Liberia and southern Sierra Leone, thereby pushing the Golas further south into the forest belt (Gershoni 1985: 2). Traditionally seafarers who travelled along the West African coast and across the Atlantic Ocean to Europe as early as the nineteenth century, the Krus from southeastern Liberia also exhibited migratory patterns that gradually spread into 'the area between the central Liberian coast and the hinterland, up to the San Pedro River in what is now Côte d'Ivoire' (Gershoni 1985: 2). Migrants were particularly attracted to the coast because of interactions with Portuguese seamen who began making regular expeditions to trade with the local people in the mid-fifteenth century (Gershoni 1985: 3). In exchange for brass, glass, clothes, and iron supplies, the local populations traded in slaves, skins, gold and ivory (Gershoni 1985: 3).

By the time repatriated blacks arrived on the coast of pre-settler Liberia in the mid-nineteenth century, 250 years of migration had preceded them, with various ethnolinguistic communities virtually settled in their confederations of clans and chieftaincies, 'traditions of alliances, and rivalries' (Gershoni 1985: 3-4). Between 1822 and 1867, the American Colonization Society (ACS) facilitated the emigration of 18,858 blacks to Liberia, and of the total, 6,000 emigrants had been granted freedom on the condition that they leave the United States; others were either born free or had already purchased their freedom (Gershoni 1985: 8). Although recaptives from the Congo River Basin trickled into pre-settler Liberia, the 1850s marked a surge in their immigration. Between 1858 and 1861 , nearly a dozen slave ships en route to Cuba and other places in the Americas were intercepted and diverted to the shores of Liberia and by late 1860, between 3,600 and 6,000 recaptives had arrived (Clegg 2004: 245; Moran 2006: 2). These numbers were augmented by a few hundred immigrants from Barbados after the abolition of slavery on that island (Moran 2006: 2).

Consequently, citizenship in post-independence Liberia was initially tied to experiences of migration with the ultimate privileging of rootlessness (Burrowes 2004: 69). Whereas Liberia's first citizens were 'rootless' immigrants with no filial ties to the land, however, the institution of citizenship became increasingly defined by markers of rootedness - residence and land ownership - in the ensuing 100 years of the republic before the decoupling of residence and citizenship altogether in the 1973 Aliens and Nationality Law and 1986 Constitution (Government of Liberia 1973, 1986; Burrowes 
2004: 69; Pailey 2014). Emigration from Liberia was rare during the early processes of state formation and later stages of attempted nation-state consolidation. Between 1946 and 1980, for instance, Liberians who could afford to travelled abroad, particularly to the United States for vacation or for studies, but rarely ever stayed for prolonged periods of time (TRC 2009: 118). After a 1980 coup toppled settler rule, however, the citizenshipas-rooted resident trope no longer held sway since Liberians fleeing subsequent crises still considered themselves citizens, albeit from afar (Pailey 2014).

Although the first Liberian-American diasporas developed at the time of settlement in the nineteenth century, Liberian diasporic identities fundamentally crystallized in the 1980 s through to the early 2000 s because of conflicts varying in scale and magnitude from 1989 to 1997 and 1999 to 2003 (Pailey 2014). Moreover, the nationstate of Liberia became fundamentally multi-territorialized during intermitted armed warfare, with a sizeable number of Liberians scattered throughout the globe, yet still fully engaged transnationally (Pailey 2014). In the 1990s and early 2000s, Liberia represented one of the highest refugee producing countries in Africa, with various sources estimating that hundreds of thousands of Liberians fled to locations as diverse as Ghana (with a refugee settlement exceeding 30,000 Liberians as of 2007), Sierra Leone, Côte d'Ivoire and Guinea in the West African sub-region, which hosted as many as 780,000 Liberian refugees in 1996 (Black et. al 2006: 5; UNHCR 2007). Liberians also fled to other destinations around the globe, particularly the United Kingdom, Sweden, and Norway in Western Europe and Providence, Rhode Island, Minneapolis/St. Paul, Minnesota, Philadelphia, Pennsylvania, and Staten Island, New York, in the United States, though the exact number in these regions is contested (Scott 1998; USDS 2001; Lubkemann 2008; Advocates for Human Rights 2009; TRC 2009). Furthermore, it is unclear how many Liberians actually reside abroad today, with the statistics on return migration to Liberia equally as inconclusive.

Regardless of the dearth of reliable data on contemporary migration flows for Liberia, unprecedented waves of conflict-generated emigration have undoubtedly touched the lives of all Liberians thereby invariably influencing the proposal for dual citizenship. This was corroborated by the bill's chief sponsor, Cletus Wotorson, who argued that its premise lay in responding to the needs of Liberians who emigrated as a result of intermittent armed conflict:

.... a lot of them [Liberians abroad] had to change their lifestyle, accept the dictates from a strange country, for survival, in some countries it meant you had to become [a] citizen of that country, to enjoy the benefits...It's a temporary means of getting their aims accomplished. But in taking that involuntary stance, it qualified them for disqualification of their citizenships in their own country, which, I believe, is unfair. ${ }^{3}$

Table 1: First-time migration patterns of 163 anonymized Liberian-born respondents ${ }^{4}$

\begin{tabular}{|l|l|l|l|l|l|l|}
\hline Field Site/ & Left & Left & Left & Left & Left & Never \\
Migration & Liberia & Liberia & Liberia & Liberia & Liberia & Left \\
Patterns & before & between & between & between & after & Liberia \\
& 1980 & $1980-$ & 1990 and & 1998 and & 2003 & \\
& & 1989 & 1997 & 2003 & & \\
\hline
\end{tabular}




\begin{tabular}{|l|l|l|l|l|l|l|}
\hline London (28) & 1 & 10 & 14 & 2 & 1 & N/A \\
\hline Washington (24) & 1 & 9 & 10 & 3 & 1 & N/A \\
\hline Freetown (15) & N/A & 2 & 7 & 2 & 4 & N/A \\
\hline Accra (30) & N/A & 3 & 19 & 7 & 1 & N/A \\
\hline Monrovia (66) & 1 & 6 & 25 & 6 & 2 & 26 \\
\hline $\begin{array}{l}\text { Total Absolute } \\
\text { Number/ } \\
\begin{array}{l}\text { Percentage of } \\
\text { Total }\end{array}\end{array}$ & $\mathbf{3} /$ & $\mathbf{3 0} /$ & $\mathbf{7 5 /}$ & $\mathbf{2 0 /}$ & $\mathbf{9 /}$ & $\mathbf{2 6 /}$ \\
\hline
\end{tabular}

Source: Pailey 2014

As Table 1 indicates, the highest spike in first-time migration amongst Liberian-born anonymized respondents in my study occurred during Liberia's first armed conflict, which brought Charles Taylor to power in 1997. Unsurprisingly, first-time migration also increased from the 1980 coup to the onset of the first insurgency by Taylor in 1989. Of the twenty-eight London-based Liberian-born respondents, twelve had spent some time in Sierra Leone, Guinea, Gambia, Côte d'Ivoire or Nigeria before settling in the UK, proving that West Africa served as a transit point before settlement. Of the twenty-four Washington-based Liberian-born respondents, only four had transited for some time through another African country - namely Nigeria, Guinea, Zimbabwe or Ghana - before settling in the US. Of the fifteen Freetown-based Liberian-born respondents, only three had transited through Guinea, Côte d'Ivoire, Ghana or Nigeria before initially settling in Freetown; the other twelve travelled directly to Freetown. This is unsurprising given that Liberia and Sierra Leone share a common border. Of the thirty Accra-based Liberianborn respondents, five had spent some time in the US or Europe before settling in Ghana, while five had passed through Togo, Guinea, Sierra Leone, or Nigeria before settling in Ghana. The remaining twenty had travelled to Ghana directly from Liberia. Of the twenty-four homeland Liberians who had travelled abroad, many had migrated for short stints to the West African sub-region before returning subsequently to Liberia. Quite often their migratory patterns were circular in nature, with out-migration peaking during times of conflict and return migration increasing during times of relative peace. These varying trends are supported by the academic literature, which argues that contemporary migration is neither unidirectional nor permanent (Leitner 2003: 450-1).

From the numbers tabulated in Table 1, it becomes clear that the migration patterns of Liberian-born 'unofficial' anonymized interviewees in my study are a particularly stark illustration of how migration became a mainstay in contemporary Liberian demography, which undoubtedly motivated Wotorson and his co-sponsors to propose dual citizenship as a worthwhile policy imperative. Of the 163 Liberian-born anonymized respondents, eighty-four per cent had travelled outside the territorial confines of the nation-state at some point in their lives. Though sixteen per cent, principally homeland Liberians, had never travelled internationally, all interviewees admitted to having at least one relative abroad, primarily as a consequence of armed conflict. Although I do not make any claims that the percentages captured in the table are representative of Liberians worldwide, I can speculate that they likely mirror Liberians' first-time migration patterns, which indubitably influenced the proposed dual citizenship 
bill. In the sections that follow, I explore how migration has simultaneously expanded and contracted the menu of legal citizenship options for Liberians thereby influencing their perspectives on the merits/demerits of bounded or unbounded 'Liberian citizenship'.

\section{A complex web of citizenship configurations}

'Liberian citizenship' has become exceedingly nuanced and multi-dimensional, largely brokered by processes of migration, as demonstrated by Table 2 capturing the varied citizenship status of respondents in this study. While the first category was born in Liberia and retained jus soli ("law of the soil", by birth) "Liberian citizenship', the second category was born in Liberia, but naturalized in a foreign country and retained foreign citizenship by naturalization. Whereas the third category of respondents was born in Liberia, but retained the foreign citizenship of at least one foreign citizen parent, the fourth category was born outside Liberia to at least one Liberian citizen parent and retained jus soli foreign citizenship. The final category was born outside Liberia to at least a Liberian citizen father and retained jus sanguinis ("law of the blood", by parentage $)^{6}$ 'Liberian citizenship'.

As Table 2 indicates, the majority of anonymized respondents in my study were Liberian born, Liberian citizens (sixty-five per cent), followed by Liberian-born, naturalized foreign citizens (twenty-four per cent). Although these statistics may not be representative, they do indicate that slightly higher numbers of Liberians maintained their legal 'Liberian citizenship' than naturalized abroad, contrary to popular lore. Thus, one assumption underlying the introduction of proposed dual citizenship legislation - that Liberians abroad have naturalized in record numbers - may be more politically motivated than factual and based on sentiments rather than empirical evidence (Pailey 2013).

Table 2: Citizenship status of 181 anonymized respondents ${ }^{7}$

\begin{tabular}{|c|c|c|c|c|c|}
\hline $\begin{array}{l}\text { Field Site/Citizenship } \\
\text { Status }\end{array}$ & $\begin{array}{l}\text { Jus Soli } \\
\text { Liberian } \\
\text { Citizen }\end{array}$ & $\begin{array}{l}\text { Liberian } \\
\text { Born, } \\
\text { Naturalized } \\
\text { Foreign } \\
\text { Citizen } \\
\end{array}$ & $\begin{array}{l}\text { Liberian } \\
\text { Born, Jus } \\
\text { Sanguinis } \\
\text { Foreign } \\
\text { Citizen } \\
\end{array}$ & $\begin{array}{l}\text { Jus Soli } \\
\text { Foreign } \\
\text { Citizen of } \\
\text { Liberian } \\
\text { parentage }\end{array}$ & $\begin{array}{l}\text { Foreign } \\
\text { Born, Jus } \\
\text { Sanguinis } \\
\text { Liberian } \\
\text { Citizen } \\
\end{array}$ \\
\hline London (30) & 6 & 22 & $\mathrm{~N} / \mathrm{A}$ & 2 & N/A \\
\hline Washington (30) & 11 & 12 & 1 & 6 & $\mathrm{~N} / \mathrm{A}$ \\
\hline Freetown (20) & 12 & 3 & $\mathrm{~N} / \mathrm{A}$ & 3 & 2 \\
\hline Accra (30) & 29 & 1 & $\mathrm{~N} / \mathrm{A}$ & $\mathrm{N} / \mathrm{A}$ & $\mathrm{N} / \mathrm{A}$ \\
\hline Monrovia (71) & 59 & 6 & 1 & 4 & 1 \\
\hline $\begin{array}{l}\text { Total Absolute } \\
\text { Number/Percentage } \\
\text { of Total }\end{array}$ & $\begin{array}{l}117 / \\
65\end{array}$ & $\begin{array}{l}44 / \\
24\end{array}$ & $\begin{array}{l}2 / \\
1\end{array}$ & $\begin{array}{l}15 / \\
8\end{array}$ & $\begin{array}{l}3 / \\
2\end{array}$ \\
\hline
\end{tabular}

Source: Pailey 2014 
The third largest category of respondents (eight per cent) were Liberians born abroad who automatically obtained jus soli foreign citizenships, a function of the complex and varied migratory patterns and circumstances of Liberians worldwide. The respondents in this study who were born outside of Liberia before the onset of contemporary conflict in 1980 admitted that their parents lived abroad because of school or work opportunities. This is supported by demographic migration trends for Liberians pre-1980. Contrastingly, jus soli foreign citizen respondents born 1980 and after admitted that they were born abroad because of continued instability in Liberia.

One of the most salient ways in which migration reconfigured 'Liberian citizenship' is that it created a hybrid category of simultaneous jus soli foreign citizens/jus sanguinis Liberian citizens. By virtue of Liberia's 1973 Aliens and Nationality Law, dual citizenship is recognized for these conditional Liberian citizens although they must decide by eighteen (the "age of majority") whether to maintain their foreign citizenship by birth or their 'Liberian citizenship' by parentage (Government of Liberia 1973). Other categories of Liberians tend to further complicate what appear to be clearly defined stipulations on citizenship in the Aliens and Nationality Law, such as jus soli Liberians who retained their foreign citizenship by virtue of being born to at least one foreign citizen parent (one per cent of the respondent pool) and jus sanguinis Liberians born abroad who retained their legal 'Liberian citizenship' by virtue of having at least a Liberian citizen father (one per cent of the respondent pool). These two categories of Liberians were fewer in number in my study, although I suspect that a comprehensive quantitative study will show they represent a larger percentage of the overall Liberian emigrant pool. Liberian-born jus sanguinis foreign citizens and foreign-born jus sanguinis Liberian citizens occupy a unique space within the 'Liberian citizenship' continuum because they made choices that were contrary to their native-born citizenship status. While the jus soli Liberians took on the foreign citizenships of their foreign-born parents by age 18, their jus sanguinis counterparts maintained the citizenship of their Liberian-born citizen parents.

Motivations for making divergent, personal choices about which citizenship to maintain are entangled in a complex web of sedentarist and nomadic metaphysics. It is also indicative of contestations about what it means to practice de jure or de facto 'Liberian citizenship' and what it means to be Liberian 'officially' or 'unofficially.' As a case in point, the highest proportion of 'unofficial' anonymized Liberian-born respondents in my study (sixty-five per cent) retained their legal Liberian citizenships, with a disproportionate number represented by diasporas in Accra and Freetown and Monrovia-based homelanders. Of the fifty homeland Liberians, slightly over half (fiftytwo per cent) said they had never travelled outside of Liberia, and therefore would not have been eligible for foreign citizenships. Of the 110 total anonymized Liberian diaspora respondents, slightly over fifty per cent retained their legal Liberian citizenships despite having lived abroad for long periods of time. In the UK and US, London-based Liberians naturalized at a far greater rate than their Washington-based counterparts. In Sierra Leone and Ghana, however, the number of naturalized Liberians in Freetown and Accra is negligible. This demographic trend could be attributed to the fact that while Sierra Leonean and Liberian identity/citizenship are mutually inclusive, sixty per cent of the Liberian-born Liberian citizens in Accra were refugees and therefore ineligible for foreign citizenships before a cessation clause was enacted in 2012 stripping Liberians 
worldwide of their refugee status, with a few outliers here and there who qualified for exemption (UNHCR 2012). Of the fifty diasporas in Freetown and Accra, slightly less than half (forty-eight per cent) were refugees who would not have been eligible for foreign citizenships without formal resettlement proceedings.

Nevertheless, ineligibility does not necessarily lessen one's hunger to naturalize, particularly in the so-called Global North. The record numbers of Liberians who apply annually for the Diversity Immigrant Visa (DV) Programme ${ }^{8}$ to travel to the US or who still yearn for resettlement in Australia and Europe despite the cessation of automatic refugee status for Liberians abroad proves that ineligibility does not evidence diminished desire. Similarly, eligibility does not necessarily evidence a strong compulsion to naturalize. Many respondents in my study held onto their legal Liberian citizenships despite being eligible to naturalize abroad. Furthermore, for those who naturalized, the decision was often slow, measured and calculated. In the next section, I explore how respondents' decisions to naturalize or not naturalize were largely contingent upon their lived experiences of migration as well as influenced by unconscious alignment with sedentarist and nomadic metaphysical paradigms around rootedness and rootlessness, respectively.

\section{Between rootedness and rootlessness}

For the purposes of this article, I have opted to focus on how migration and extreme notions of rootedness and rootlessness have fundamentally resulted in a gridlock around dual citizenship for Liberia. Nevertheless, given that the contested bill represents a manifestation of the configurations and reconfigurations of 'Liberian citizenship' across space and time, it is worthwhile here to provide a brief analysis of how the respondents in my study actually evaluated it as a policy prescription. Of the 202 Liberians interviewed, 123 supported dual citizenship; thirty supported dual citizenship with caveats; thirtyseven rejected dual citizenship; nine expressed ambivalence about dual citizenship; and three provided no recorded response. Although the percentages captured in Table 3 are not representative of Liberians worldwide, they reveal qualitative trends in how Liberians across my respondent pool actually assess dual citizenship — as a development enabler, spoiler, neither or both.

Table 3: Breakdown of dual citizenship perspectives amongst 202 respondents

\begin{tabular}{|l|l|l|l|l|l|}
\hline $\begin{array}{l}\text { Respondent Site } \\
\text { (Number) }\end{array}$ & $\begin{array}{l}\text { Support } \\
\text { DC }\end{array}$ & $\begin{array}{l}\text { Support DC } \\
\text { with Caveats }\end{array}$ & $\begin{array}{l}\text { Reject } \\
\text { DC }\end{array}$ & $\begin{array}{l}\text { Ambivalent } \\
\text { about DC }\end{array}$ & $\begin{array}{l}\text { No } \\
\text { Recorded } \\
\text { Response }\end{array}$ \\
\hline London (32) & 27 & 3 & 0 & 2 & 0 \\
\hline Washington (33) & 26 & 3 & 4 & 0 & 0 \\
\hline Freetown (21) & 18 & 1 & 1 & 1 & 0 \\
\hline Accra (33) & 20 & 4 & 7 & 1 & 1 \\
\hline Monrovia (83) & 32 & 19 & 25 & 5 & 2 \\
\hline $\begin{array}{l}\text { Total Absolute } \\
\text { Number/ } \\
\text { Percentage of }\end{array}$ & $\mathbf{1 2 3 /}$ & $\mathbf{3 0} /$ & $\mathbf{3 7 /}$ & $\mathbf{9 /}$ & $\mathbf{3 /}$ \\
\hline
\end{tabular}


\begin{tabular}{|l|l|l|l|l|l|}
\hline Total & & & & \\
\hline
\end{tabular} Source: Pailey 2014

Based on statistical analysis of the respondent pool captured in Table 3, it is clear that the vast majority of interviewees - seventy-six per cent - conceive essentially of 'Liberian citizenship' as territorially unbounded and of dual citizenship as potentially enabling development and social cohesion. In sharp contrast to the perspectives of respondents in London, Washington, Freetown and Accra, the majority of whom approved of dual citizenship in principle for Liberia, the greatest resistance to dual citizenship came from Monrovia-based respondents, particularly homelanders. Of the fifty homeland interviewees, twenty-two emphatically rejected dual citizenship, either as a conceptual framework or as a legal instrument for Liberia. The majority of those who denounced dual citizenship were Liberians who admitted to physically residing in the country throughout the course of their lives. This supports my initial hypothesis that Liberians who never physically left the country might have slightly more sedentarist conceptions of 'Liberian citizenship' as territorially bounded than those who travelled for short-stints, or lived abroad for longer periods of time. Yet, the notion that authentic expression of 'Liberianness' can only be manifested in the possession of 'Liberian citizenship' exclusively, and thus rooted in one national Liberian identity, was also espoused by Monrovia-based non-homelanders and non-Monrovia based diaspora respondents, which illustrates the diffuse nature of conceptions of rootedness. It is to this perspective that I turn first.

5.1 No matter how long a rock stays in a river, it can never turn to catfish

Contrary to the assumption that all migrants clamour to attain Western citizenships, many respondents held onto their legal 'Liberian citizenship' status long after they were eligible to naturalize abroad because of deeply entrenched notions of rootedness. As a case in point, one thirty-five-year-old Monrovia-based permanent returnee, whose parents were working in East Africa at the time of his birth, retained his jus sanguinis 'Liberian citizenship' even though he was entitled to Kenyan citizenship by birth and eligible for US citizenship having lived there for over a decade as a permanent resident:

I met some Kenyan people in the UN system here [Liberia] and they were like, 'You were born in Kenya! You should apply for Kenyan citizenship; you are entitled!'...Well, I knew at the time that Liberia did not honour dual citizenship and I always felt like I would be selling my soul by going to another nationality. But that's just me. ${ }^{9}$

This respondent's decision to choose 'Liberian citizenship' from a menu of three legal identity options because of fears of 'selling his soul' mirrors the anti-assimilationist stances of Malkki's (1992) camp-based refugee subjects. Other respondents used sedentarist metaphysical language - with references to earth, soil, ashes, blood - to describe their refusal to naturalize, such as this seventy-four-year-old Washington-based US permanent resident who spent over eighteen consecutive years abroad, from the onset 
of Liberia's armed conflict in 1989: 'I refuse to become an American citizen...I told my family I must be buried in Liberia or Liberia is where my ashes are supposed to be...So, Liberia is in my blood'. 10

Another Washington-based respondent, a fifty-six-year-old man on Deferred Enforced Departure (DED) ${ }^{11}$ since migrating in 2002 and therefore ineligible to naturalize in the US, said naturalization never even occurred to him as a durable solution to his immigration limbo because 'my mind, you know, my soul...everything is out there in Liberia'. ${ }^{12}$ Other Liberians discussed the philosophical tenets of rootedness as manifested in retaining legal 'Liberian citizenship'. Evoking an African parable to describe his deep and abiding loyalty to Liberia, and motivations for not wanting to naturalize, even if eligible, one Accra-based fifty-eight-year-old former refugee who had lived in Togo previously before migrating to Ghana in 2006, said, 'No matter how long a rock stays in a river, it can never turn to catfish... it means that your nationality is just your nationality, unless you want to fool yourself'. ${ }^{13}$ The diasporic respondents whose views are explored above prove that notions of bounded citizenship as a function of rootedness are not confined to the territorially rooted. Moreover, all the respondents fundamentally agree that although they could not remain physically rooted in Liberia because of armed conflict, choosing to maintain 'Liberian citizenship' in spite of migration signified their metaphysical rootedness. The perspectives of these respondents - who indirectly adopted a sedentarist metaphysic in relation to citizenship and naturalization - completely unsettle core assumptions about how migrants from the so-called Global South are utility maximizing agents who clamour for citizenships from the so-called Global North.

At times employing symbolic imagery from slavery to describe citizens as slaves and nation-states as 'masters', some respondents who rejected dual citizenship said that Liberians who naturalized abroad had abandoned Liberia by denouncing their 'Liberian citizenship' in favour of a 'second master' thereby exhibiting no loyalty to Liberia or divided loyalties at best — essentially accusing them of being 'rootless': 'There is no way that one man can serve two masters... So, there is no way one can love two countries at heart'. 14 'Divided loyalties' was continuously defined as the exclusive domain of the rootless emigrant, by ordinary Liberians and policy makers alike, including Senator Jewel Howard Taylor, one co-sponsor of the proposed dual citizenship bill who, in a fit of lucidity and irony, expressed alarm by questioning the motives of diaspora proponents of the contested legislation:

What they're actually clamouring for is political ownership of Liberia. It's not economic; it's not developmental...Because they [diaspora Liberians] want to determine who becomes president in Liberia... So, can you imagine people want to stay in America to take advantage of the opportunities there, live in the luxury that they have, they don't care what's happening here [in Liberia], but when it's time to vote, all of them will rush home and say, 'Oh, I'm a Liberian citizen'... Liberians here [in Liberia], a lot of them are not working, they're unemployed, and they feel as if Liberians coming from the diaspora who have had all of these opportunities want to come and take their space. So, the common 
sentiment you'll find with those living in Liberia, especially the young people is, like, 'Yeah, hey! Those guys can decide whether they want to be Liberians or Americans [or another nationality]... But they can't have it both ways'... ${ }^{15}$

Although implicitly self-serving, Senator Taylor's apprehension is supported by the academic literature (Whitaker 2011). While a new body of scholarship frames citizenship and the right to a nationality as a human right among other rights in the context of migration and globalization (Manby 2010: 1-2), economic globalization has created swathes of poverty thereby fuelling anti-extraterritorial citizenship sentiments (Tan 2005: 6-7).

Taylor's position, as well as that of previous respondents', is theorized by Turner, who makes an insightful distinction between 'hot/cool loyalty' and 'thick/thin solidarity' (Turner 2000: 141). For instance, it is speculated that while people with multiple citizenships may exhibit 'cool' loyalties to any particular nation-state and 'thin' patterns of solidarity with a particular group of nationals governed within a nation-state, their single-citizenship counterparts may exhibit 'hot' loyalties and 'thick' patterns of solidarity within a particular nation-state (Turner 2000: 141). Turner's 'cool loyalty' and 'thin solidarity' frames map neatly onto some Liberians' understandings of dual citizenship as rootlessness personified, as articulated by this twenty-eight-year-old Monrovia-based woman who returned to Liberia after twenty-one years abroad:

If people have dual citizenship they are basically in a win-win situation because it almost forces them not to be deeply rooted somewhere. It's just like if they are in Liberia, if something pops up they can just pick up and leave to go somewhere else. So, there is this level of, like, non-attachment to a place. So, I think that, and in the case of Liberia, having people not be deeply rooted and not be attached to this place could possibly be dangerous... ${ }^{16}$

It is this respondent's perspective that I turn to now to demonstrate that although conflict in Liberia may have presented few options beyond migration, settlement in a host country does not necessarily compel one to naturalize, thereby revoking legal 'Liberian citizenship'. Thus, backlash against proposed dual citizenship legislation rests on the fundamental interrogation of whether or not naturalization is by force. One thirty-sixyear-old female Monrovia-based permanent returnee who had lived in Ghana previously as a refugee for eleven years, argued vehemently that naturalization is a matter of choice:

...you are free to decide whether you want to be a citizen or you don't want to be a citizen [of Liberia]...I think it's a lame argument to say that because you wanted to leverage on the opportunities available [abroad], that's why you became a citizen [abroad] and now you want to enjoy the benefits of both countries...It's [Liberian citizenship's] your birth right, the [Liberian] Constitution recognizes your birth right, but it also recognizes the fact that you have a will to decide to continue to maintain your birth right or to give it up. ${ }^{17}$ 
Similar to the structure versus agency debate still raging in modern sociological theory, the line appears blurred between force and choice in motivations for migrating or naturalizing, where eligible (Van Hear et al 2009). For respondents in my study, however, deciding not to naturalize when eligible was framed as a choice for respondents attempting to validate their presumed rootedness.

\subsection{The passport can change but the heart cannot}

While the motivations for not naturalizing abroad—largely based on sedentarist metaphysics - have challenged core assumptions about the necessity of dual citizenship for Liberia, motivations for naturalizing — largely based on nomadic metaphysics - have galvanized proponents of such a policy prescription. It is to this perspective that I now shift, arguing that nomadic metaphysical thinking maps onto unbounded conceptions of citizenship thus galvanizing diasporic and non-diasporic Liberians alike.

The staunchest supporters of dual citizenship were those who acknowledged the expanded political and economic entitlements of naturalization, with the practical need to survive abroad trumping impractical, idealized notions of 'Liberian citizenship' authenticity. For example, a Monrovia-based homelander who still carries a US Green Card though he has not lived in the United States since 1998, defended the decision of his relatives who naturalized abroad and other Liberians who felt compelled to take on foreign citizenships:

...In 1990, because of the war, I became a [US] resident. We all filed for political asylum...As old as my parents were at the time, they took on American citizenship because it afforded certain benefits in the US as old people...I have siblings who live here [in Liberia] permanently, and had Green Cards, and just said, 'Just for the hell of it, I'm going to get an American citizenship'. ${ }^{18}$

For many respondents, the immediate gratification of naturalization outweighed the guilt of revoking their legal 'Liberian citizenship' status. While ease of travel did not appear to be a major motivator for Washington-based respondents who naturalized, their Londonbased counterparts constantly referenced it as an impetus for taking on UK citizenship. This could be attributed to the fact that as a global city London represents a hub, with very accessible European Union, African, North American and Asian flight routes. One respondent, a thirty-six-year-old London-based woman who relocated to the UK for school a few years before Liberia's first armed conflict, said that after she obtained the red British passport in 2000, she began to recognize the international system of citizenship tiers, as theorized by Yuval-Davis (2000), in which passport-holders from the so-called Global North are treated better than passport-holders from the so-called Global South, particularly Africa. ${ }^{19}$ Also lamenting the limitations of travel with a Liberian passport, a forty-seven-year-old London-based male respondent who had lived in the USSR and US previously, said: 'Our passports are not respected equally...A British passport holder can go anywhere in the world but a Liberian passport holder cannot go anywhere in the world. ${ }^{20}$ 
Contrary to the sedentarist bias that frames stasis as 'the natural order of things' (Malkki 1992), the most strident supporters of dual citizenship were diasporic Liberians who interrogated physical rootedness, particularly within conflict contexts, as somehow more desirable or authentic. According to the thirty-six-year-old female respondent previously mentioned, escape and exile were natural responses to the dredges of armed conflict, and, as such, migration and mobility should underpin Liberia's current citizenship norms:

It's interesting because we hadn't experienced 'the war', there were times when people would make that almost a criteria of being [a] Liberian [citizen]. And I'm like, 'Hello!', you know, 'I don't think I need to dodge bullets to qualify as a Liberian [citizen]'. ${ }^{21}$

Yet, direct war-time experiences embolden claims to 'Liberian citizenship', argued then foreign affairs minister and homelander, Augustine Ngafuan:

There are a lot of people here who feel that they did not run away from the country [during the war]... Whatever they got in the swamp they ate and they survived...they went through check-points, and they were here [in Liberia] for all the wars...They take some of their brothers that come from the diaspora as those who chickened out. 'When those times of difficulties existed, you were more than glad to run away and not to face the burden with us. Now that the country has gotten stable and opportunities are coming, then you come and say you are a Liberian [citizen], ${ }^{22}$

Other respondents argued that Liberians' tactile experiences of armed conflict caused by the ruthless and rootless Charles Taylor coupled with the searing memory of seeing some Liberians with other citizenships escape carnage serve as a major indictment of unbounded citizenship regimes:

When the war started those who had other citizenships, they all fled. They all left, and those of us who didn't have, we had to stay there [in Liberia] and go through [it], even though some of the problems were caused by them. ${ }^{23}$

Indeed, it is because of the experience of armed conflict that some Liberians either reject dual citizenship entirely or insist on instituting measures to curb abuse if it is enacted.

Nevertheless, those who adopt a nomadic metaphysic, like this thirty-six-year-old Freetown-based man, argue that Liberians who migrate, naturalize abroad and maintain transnational ties contribute not only to the rich tapestry of the country's amalgamated identities but also to development, and therefore should be able to maintain their jus soli or jus sanguinis 'Liberian citizenship':

If a man must contribute to his nation, most especially like Liberia, the man must go out [of the country]. And if the man goes out, he acquires knowledge that can help Liberia. If you will stop a man from being a 
citizen in another country that will be contributing to the man's development and indirectly contributing to the nation, Liberia, then it means you'll be hindering the development in Liberia...I support dual citizenship [one] hundred per cent because the book [passport] can change but the heart cannot change. ${ }^{24}$

That migration defines Liberia's past, present and future is a surety, and for those who espoused views aligned with nomadic metaphysical thinking, they argued that unbounded citizenship is the norm rather than the exception. As a case in point, a forty-four-year-old Monrovia-based circular returnee man born in the US to Liberian citizen parents, defended why Liberians of his ilk should be able to legitimately carry two passports:

As a post-war country, we should be clamouring, we should be clawing, screaming, fighting tooth and nail to make sure that everyone who even has an inkling of wanting to be considered Liberian, particularly if they have something to offer, we should be fighting to get them to be Liberian. There is no reason why we should have a nuclear physicist or two, or three, or four, an endocrinologist, a general surgeon or four, or five or six whatever, out there who by simple virtue of their partial parentage or perhaps during the war years, they were born outside this country [Liberia] but they actually want to identify with Liberians...there is no reason why we should not be pulling those people in. ${ }^{25}$

Such an impassioned appeal reinforces the argument that dual citizenship is of significant importance to respondents who lead transnational lives, as they would be the primary beneficiaries of legislation in this regard, as articulated by this fifty-five-year-old US born, Monrovia-based permanent returnee who said she practiced de facto dual citizenship because of her doubly inscribed identity:

I feel that I am a Liberian and I feel that I am an American by birth. And I feel that these two countries are not in war, they're not in conflict. I'm not aspiring to be president or any high government official, personally. So, what is the conflict? ${ }^{26}$

As illustrated by this respondent's strong defence of dual citizenship, Liberians' motivations for seeking other citizenships are varied, complex and largely based on migration experiences, constraints and opportunities leading to the adoption of nomadic metaphysical thinking.

\section{Conclusion}

As Liberia transformed from a country of immigration to emigration, so too did its citizenship construction change, with migration configuring and reconfiguring 'Liberian citizenship' across space and time. In 1847, Liberia was a country of relative immigration, nonetheless citizenship norms were biased against those who were deemed 'rooted'primarily the 16 ethnic groups already occupying the territory were formally excluded 
from the institution of citizenship. In 2017, however, while Liberia is a country of relative emigration, citizenship norms remain biased against those who are considered 'rootless' - essentially, jus soli Liberians who naturalized abroad and jus sanguinis Liberians who maintained their citizenships by birth are excluded from formal 'Liberian citizenship'. While Liberians grapple with tensions between sedentarist and nomadic metaphysical understandings of identity and place, the country must reconcile contradictions between bounded and unbounded conceptions of citizenship while also flexing its muscle within a region increasingly expanding regimes of political subjectivity. I have demonstrated herein that those who view naturalization abroad as a legitimate response to protracted conflict view 'Liberian citizenship' through a nomadic metaphysical lens, while those who adopt a sedentarist metaphysic argue that naturalization is an illegitimate revocation of 'Liberian citizenship' as legal, cultural and national identity. Through an exploration of the complex and varied citizenship status choices of the respondents in my study, I showed how Liberia's proposed dual citizenship bill is an attempt to reconcile the migration of hundreds of thousands of Liberians before, during, and after intermittent armed conflicts. This article illustrated, however, that dual citizenship enactment has stalled because although some Liberians acknowledge some migration as involuntary, others view naturalization outside Liberia as a fundamental denial of what it means to be a Liberian citizen, rooted both in name and in practice. 


\section{References}

Advocates for Human Rights (2009) The House with Two Rooms: Final Report of the Truth and Reconciliation Commission of Liberia Diaspora Project. Saint Paul: Dispute Resolution Institute (DRI) Press.

Black, Richard, Crush, Jonathan, and S. Peberdy et. al (2006) 'Migration and Development in Africa: An Overview’, African Migration and Development Series No. 1, South African Migration Project (SAMP). Cape Town: Idasa.

Burrowes, Carl Patrick (2004) Power \& Press Freedom in Liberia, 1830-1970. Trenton, New Jersey: African World Press, Inc.

Clegg, Claude Andrew III (2004) The Price of Liberty: African Americans and the Making of Liberia. Chapel Hill and London: The University of North Carolina Press.

Cresswell, Tim (2006) On the Move: Mobility in the Modern Western World. London: Routledge.

Daily Observer (2016), '7 Propositions Passed for Referendum' (Monrovia; pubd online November 2016) <http://www.liberianobserver.com/news/7-propositions-passedreferendum $>$ accessed 28 November 2016.

Dannreuther, Roland (2007) International Security: The Contemporary Agenda. Cambridge: Polity.

Desforges, Luke, Jones, Rhys and Woods, Mike (2005) 'New Geographies of Citizenship', Citizenship Studies, 9/5: 439-51.

Duffield, Mark (2008) 'Global Civil War: The Non-Insured, International Containment and Post-Interventionary Society’, Journal of Refugee Studies, 21/2: 145-165.

Gershoni, Yekutiel (1985) Black Colonialism: The Americo-Liberian Scramble for the Hinterland. Boulder: Westview Press, Inc.

Glick Schiller, Nina (2009) 'A Global Perspective on Transnational Migration: Theorizing Migration without Methodological Nationalism', Centre on Migration, Policy and Society (COMPAS) Working Paper No. 67, Oxford: University of Oxford.

Government of Liberia (1973) Aliens and Nationality Law of Liberia. Monrovia: Government of the Republic of Liberia.

Government of Liberia (1986) Constitution of the Republic of Liberia, Republic of Liberia. Monrovia: Government of the Republic of Liberia. 
Guannu, Joseph Saye (1983) Liberian History up to 1847. New York: Exposition Press, Inc.

Isin, Engin F. (2000) 'Introduction: Democracy, Citizenship and the City'. In: Isin EF (ed) Democracy, Citizenship and the Global City, pp. 1-21. Routledge: London.

Konneh, Augustine (1996) Religion, Commerce, and the Integration of the Mandingo in Liberia. Lanham: University Press of America, Inc.

Leitner, Helga (2003) 'The Political Economy of International Labour Migration'. In: Sheppard E and Barnes T (eds) A Comparison to Economic Geography, pp. 450-67. Blackwell Publishing: Oxford.

Liberia News Agency (2015), 'CRC Delegates Vote on 13 of 25 Propositions So Far' (Monrovia; pubd online April 2015)

$<$ http://www.liberianewsagency.org/pagesnews.php?nid=4448> accessed 28 Nov 2016.

Lubkemann, Stephen C. (2008) 'Remittance Relief and Not-Just-for Profit Entrepreneurship: The Case of Liberia'. In Brinkerhoff JM (ed) Diasporas and Development: Exploring the Potential, pp. 45-66. Lynne Rienner Publishers: Boulder and London.

Malkki, Liisa H. (1992) 'National Geographic: The Rooting of Peoples and Territories and the Territorialization of National Identity among Scholars and Refugees', Cultural Anthropology, 7/1: 24-44.

Mamdani, Mahmood (1996) Citizen and Subject. Princeton: Princeton University Press.

Manby, Bronwen (2009) Struggles for Citizenship in Africa. London and New York: Zed Books.

Manby, Bronwen (2010) Citizenship Law in Africa: A Comparative Study. New York and Johannesburg: Open Society Foundations.

Manby, Bronwen (2016) Citizenship Law in Africa: A Comparative Study. New York and Johannesburg: Open Society Foundations.

Moran, Mary H. (2006) Liberia: The Violence of Democracy. Philadelphia: University of Pennsylvania Press.

Pailey, Robtel Neajai (2013) 'Why Liberia's Proposed Dual Citizenship Bill Should Be Based on Evidence and Not Sentiments' (pubd online July 2013) $<$ http://africanarguments.org/2013/07/18/why-liberias-proposed-dual-citizenshiplegislation-should-be-based-on-evidence-not-sentiments-by-robtel-neajai-pailey/> (accessed 9 July 2017). 
Pailey, Robtel Neajai (2014) The Love of Liberty Divided Us Here? Factors Leading to the Introduction and Postponement in Passage of Liberia's Dual Citizenship Bill (unpublished $\mathrm{PhD}$ thesis), SOAS, University of London.

Pailey, Robtel Neajai (2016) 'Birthplace, Bloodline and Beyond: How 'Liberian Citizenship' Is Currently Constructed in Liberia and Abroad', Citizenship Studies, 20/6-7: $811-29$.

Scott, C. (1998) 'Liberia: A Nation Displaced'. In: Cohen R and Deng F (eds) The Forsaken People: Case Studies of the Internally Displaced, pp. 97-138. Brookings Institute: Washington, DC.

Siaplay, Mounir (2014) 'Do Countries that Recognize Dual Citizenship Have Healthier Economies? Evidence from the Economic Community of West African States', Migration and Development, 3/2: 254-71.

Tan, Sor-hoon (2005) 'Introduction: Globalization and Citizenship'. In: Tan S (ed) Challenging Citizenship: Group Membership and Cultural Identity in a Global Age, pp. 1-14. Ashgate: Surrey, UK and Burlington, Vermont.

Truth and Reconciliation Commission of Liberia (TRC) (2009) Volume II: Consolidated Final Report. Monrovia: TRC of Liberia.

Turner, Bryan S. (2000) 'Cosmopolitan Virtue: Loyalty and the City'. In Isin EF (ed) Democracy, Citizenship and the Global City, pp. 129-47. London: Routledge.

United Nations High Commissioner for Refugees (UNHCR) (2007) '2005 UNHCR Statistical Yearbook Liberia (400-401)'. Geneva: UNHCR.

United Nations High Commissioner for Refugees (UNHCR) (2012), 'End of Refugee Status for Angolan and Liberian Exiles This Weekend' (Geneva, pubd June 29) $<$ http://www.unhcr.org/uk/news/briefing/2012/6/4fed82459/end-refugee-status-angolanliberian-exiles-weekend.html $>$ accessed 28 Dec 2016.

United States Department of State (USDS) (2001) Country Human Rights Report 2000. Washington, DC: Bureau of Democracy, Human Rights and Labour.

Urry, John (2000) 'Global Flows and Global Citizenship'. In: Isin EF (ed) Democracy, Citizenship and the Global City, pp. 62-78. Routledge: London.

Van Hear, Nicholas, Brubaker, Rebecca and Bessa, Thais (2009) 'Managing Mobility for Human Development: The growing salience for mixed migration', United Nations Development Human Development Reports, Research Paper 2009/20. New York, UNDP.

Whitaker, Beth Elise (2011) 'The Politics of Home: Dual Citizenship and the African Diaspora', International Migration Review, 45/4: 755-83. 
Yuval-Davis, Nira (2000) 'Citizenship, Territoriality and the Gendered Construction of Difference'. In: Isin EF (ed) Democracy, Citizenship and the Global City, pp. 171-88. Routledge: London.

\footnotetext{
${ }^{1}$ If enacted, the bill would enable Liberian citizen women to pass on citizenship to their children as well as grant dual citizenship to Liberians by birth who naturalized elsewhere (or have aspirations to naturalize), and those born outside of Liberia to Liberian citizen parents, respectively.

${ }^{2}$ During 14 months of fieldwork across five urban centres in Liberia and abroad, I deliberately sought out Liberian respondents of different ages, genders, educational levels, incomes, places of birth, countries of citizenship and migration histories. I balanced my interviews with 181 diaspora, homeland and returnee respondents speaking unofficially with 21 respondents speaking in their official capacities as government of Liberia representatives or regional diaspora heads of organizations. Since the research methodologies employed in this study were meant to be exploratory rather than representative, interviewees were selected through a snowball sampling method, in which I contacted individuals I knew personally or professionally, and asked them to recommend others who fit within my analytical categories - namely executive branch policy makers (whose ministries/agencies represented pillars on which Liberia's post-war recovery agenda from 2006-2011 was built), legislative branch policy makers (four sponsors of the proposed dual citizenship bill), diasporas, permanent returnees (individuals who considered the current move to Liberia a permanent move), circular returnees (those who returned to live in Liberia for at least 12 consecutive calendar months - but less than six consecutive years - within the past decade) and homelanders (Liberians who had spent most, if not all, their lives in Liberia before the first war started in 1989, and most, if not all, their lives in Liberia after the first postwar moment in 1997). The basic criterion for the selection of Liberian interviewees speaking unofficially was their self-identification as Liberians regardless of citizenship status.

${ }^{3}$ Interview in Monrovia on 6 March 2013.

${ }^{4}$ I did not capture the migratory patterns of foreign-born Liberians in this table because I wanted to establish a baseline of first-time migration for those who were born in the country. I deliberately refrained from explicitly asking the 21 government officials and heads of regional organizations about their migration patterns, as I realized early on that this information was not necessary for my analysis.

${ }^{5}$ Jus soli ("law of the soil") refers to citizenship by one's place of birth.

${ }^{6}$ Jus sanguinis ("law of the blood") refers to citizenship by one's parentage.

${ }^{7}$ I refrained from explicitly asking the 21 government officials and heads of regional organizations about their citizenship status, as I realized early on that this would be a sensitive subject to broach for those speaking in their official capacities. Therefore, this information is not captured in my analysis.

${ }^{8}$ According to the US Department of State website, the Diversity Visa Immigration (DV) Programme enables 'diversity immigrants' from countries with historically low rates of immigration to the United States' to apply for a limited number of visas available annually. These visas enable recipients to eventually become eligible for US permanent residency and citizenship, http://travel.state.gov/content/visas/english/immigrate/diversity-visa/entry.html

${ }^{9}$ [PR7] Interview in Monrovia on 25 June 2013

${ }^{10}$ [DL48] Interview in Washington on 24 October 2012.

${ }^{11}$ Since 1991, thousands of Liberians have relied on renewable, short-term provisions such as DED granted by the White House to extend their legal right to remain in the US. These individuals, many of whom have been in the United States since fleeing Liberia in the late 1980s
} 
and early 1990s, have retained legal status which allows them to live, work, and pay taxes in the US.

${ }^{12}$ [DL52] Interview in Washington on 25 October 2012.

${ }^{13}$ [DL101] Interview in Accra on 19 May 2013.

${ }^{14}$ [HL17] Interview in Monrovia on 12 June 2013.

${ }^{15}$ Interview in Monrovia on 6 March 2013.

${ }^{16}$ [CR10] Interview in Monrovia on 27 June 2013.

${ }^{17}$ [PR5] Interview in Monrovia on 17 June 2013.

${ }^{18}$ [HL18] Interview in Monrovia on June 12, 2013.

${ }^{19}$ [DL8] Interview in London on June 13, 2012.

${ }^{20}$ [DL27] Interview in London on June 22, 2012.

${ }^{21}$ [DL8] Interview in London on 13 June 2012.

${ }^{22}$ Interview in Monrovia on 11 June 2013.

${ }^{23}$ [DL104] Interview in Accra on 20 May 2013.

${ }^{24}$ [DL62] Interview in Freetown on 11 April 2013.

${ }^{25}$ [CR2] Interview in Monrovia on 5 June 2013.

${ }^{26}$ [PR2] Interview in Monrovia on 7 June 2013. 